\title{
Aqueous Extracts of Corni Fructus Protect C2C12 Myoblasts from DNA Damage and Apoptosis Caused by Oxidative Stress
}

\section{Sung Ok Kim ( $\nabla$ sokim@ks.ac.kr)}

Kyungsung University https://orcid.org/0000-0002-6929-9245

\section{Yung Hyun Choi}

Dong-Eui University

\section{Eunjoo H. Lee}

Kyung Hee University https://orcid.org/0000-0002-5569-0067

\section{Research Article}

Keywords: Corni Fructus, myoblasts, ROS, DNA damage, apoptosis

Posted Date: October 25th, 2021

DOI: https://doi.org/10.21203/rs.3.rs-980552/v1

License: (c) (i) This work is licensed under a Creative Commons Attribution 4.0 International License. Read Full License

Version of Record: A version of this preprint was published at Molecular Biology Reports on April 26th, 2022. See the published version at https://doi.org/10.1007/s11033-022-07332-1. 


\section{Abstract}

Background Although the various pharmacological effects of Corni Fructus are highly correlated with its antioxidant activity, the blocking effect against oxidative stress in muscle cells is not clear. The purpose of this study was to investigate the effect of aqueous extracts of Corni Fructus (CFE) against oxidative stress caused by hydrogen peroxide $\left(\mathrm{H}_{2} \mathrm{O}_{2}\right)$ in murine skeletal $\mathrm{C} 2 \mathrm{C} 12$ myoblasts.

Methods and results MTT assay for cell viability, DCF-DA staining for reactive oxygen species (ROS) production, Comet assay for DNA damage, annexin V-FITC and PI double staining for apoptosis, JC-1 staining and caspase assay for monitor mitochondrial integrity, and western blotting for related protein levels were conducted in $\mathrm{H}_{2} \mathrm{O}_{2}$ oxidative stressed $\mathrm{C} 2 \mathrm{C} 12$ cells. Our results showed that CFE pretreatment significantly ameliorated the loss of cell viability and inhibited apoptosis in $\mathrm{H}_{2} \mathrm{O}_{2}$-treated $\mathrm{C} 2 \mathrm{C} 12$ cells in a concentration-dependent manner. DNA damage induced by $\mathrm{H}_{2} \mathrm{O}_{2}$ was also markedly attenuated in the presence of CFE, which was associated with suppression of ROS generation. In addition, $\mathrm{H}_{2} \mathrm{O}_{2}$ reduced mitochondrial membrane potential and caused downregulation of $\mathrm{Bcl}-2$ and upregulation of $\mathrm{Bax}$ expression, although these were abrogated by CFE pretreatment. Moreover, CFE blocked $\mathrm{H}_{2} \mathrm{O}_{2}$-induced cytosolic release of cytochrome $c$, activation of caspase-9 and caspase-3, and degradation of poly (ADPribose) polymerase.

Conclusion Taken together, the present results demonstrate that CFE could protect C2C12 cells from $\mathrm{H}_{2} \mathrm{O}_{2}$-induced damage by eliminating ROS generation, thereby blocking mitochondria-mediated apoptosis pathway. These results indicate that CFE has therapeutic potential for the prevention and treatment of oxidative stress-mediated myoblast injury.

\section{Introduction}

Factors inducing muscle dysfunction may include loss or impairment of myoblasts and inhibition of their differentiation into muscle [1, 2]. In particular, oxidative stress and consequent mitochondrial dysfunction contribute to the pathology of myoblast damage through the production of reactive oxygen species (ROS). At the physiological level, ROS play an important role as secondary messengers in various cellular signaling pathways for maintaining cell survival and function $[3,4]$. However, excessive production of ROS is closely associated with functional impairment of various cells [3, 4]. Skeletal muscle, which consumes more oxygen than other tissues, is thought to be more susceptible to oxidative stress as mitochondria become overactivated in response to contractile [5-7]. Overproduction of ROS in muscle causes oxidative stress, resulting in cell death, including apoptosis and necrosis, following damage to macromolecules such as nucleic acids, lipids and [8,9]. Moreover, excess accumulation of ROS can reduce mitochondrial membrane potential (MMP, $\Delta \psi m$ ), one of hallmarks of impaired mitochondrial function, which acts as a cause of intrinsic apoptosis induction $[4,10]$. Therefore, blocking ROS generation and inhibiting apoptosis in myoblasts could potentially be a means of preventing muscle damage to oxidative stress. 
Corni Fructus, the fruit of Cornus officinalis Siebold \& Zucc. is one of the most traditionally used herbal medicines and is known as "Sansuyu " in Korea. Corni Fructus has been reported to have a wide range of pharmacological effects, including anti-inflammatory, glycemic control, renal protective, neuroprotective, and hepatoprotective activities [11-13]. These pharmacological activities of Corni Fructus extract and active ingredients are believed to be at least due to their antioxidant potential [14-18]. However, effects of Corni Fructus on muscle dysfunction caused by oxidative stress are still unclear. Therefore, the purpose of this study was to evaluate the protective effect of aqueous extracts of Corni Fructus (CFE) against hydrogen peroxide $\left(\mathrm{H}_{2} \mathrm{O}_{2}\right)$-caused oxidative damage in $\mathrm{C} 2 \mathrm{C} 12$ myoblasts.

\section{Materials And Methods}

\section{Reagents and antibodies}

Dulbecco's Modified Eagle's Medium (DMEM), fetal bovine serum (FBS) and antibiotics (penicillin/ streptomycin) were acquired from WelGENE Inc. (Gyungsan, Republic of Korea). $\mathrm{H}_{2} \mathrm{O}_{2}$, dimethyl sulfoxide (DMSO), 3-(4,5-dimethylthiazol-2-yl)-2,5-diphenyltetrazolium bromide (MTT), 2'7'-dichlorodihydrofluorescein diacetate (DCF-DA), 4',6'-diamidino-2-phenylindole (DAPI), paraformaldehyde, ethidium bromide (EtBr), RNase A, propidium iodide ( $\mathrm{PI}$ ) and Triton X-100 were purchased from SigmaAldrich Chemical Co. (St. Louis, MO, USA). Mitochondrial fractionation kit and annexin V-fluorescein isothiocyanate (FITC) and PI double staining kit were obtained from Active Motif, Inc. (Carlsbad, CA, USA) and Becton Dickinson (San Jose, CA, USA), respectively. Comet assay kit was purchased from Trevigen Inc. (Gaithersburg, MD, USA). Caspase enzyme-linked immunosorbent assay kits were obtained from R\&D Systems, Inc. (Minneapolis, MN, USA). Polyvinylidene fluoride (PVDF) membranes and enhanced chemiluminescence (ECL) reagent were obtained from Millipore (Bedford, MA, USA) and Amersham Biosciences (Westborough, MA, USA), respectively. Primary antibodies were purchased from Santa Cruz Biotechnology, Inc. (Santa Cruz, CA, USA), Abcam, Inc. (Cambridge, UK), and Cell Signaling Technology (Danvers, MA, USA) (Supplementary File 1). Horseradish peroxidase (HRP)-conjugated goat anti-rabbit and anti-mouse IgG antibodies were obtained from Santa Cruz Biotechnology, Inc. All other reagents were from Sigma-Aldrich Chemical Co. unless otherwise stated.

\section{CFE preparation}

Corni Fructus was kindly obtained from the Gurye Sansuyu Farming Association Corporation (Gurye, Republic of Korea), and the voucher specimen (WECU-17-2) was deposited in the Herbarium, Department of Biochemistry, Dong-eui University College of Korean Medicine (Busan, Republic of Korea). CFE was extracted as described previously [19]. Briefly, dried Corni Fructus was ground and extracted with boiled distilled water using a reflux system. The liquid extract was then filtered using filter paper (Whatman No. 4, Whatman International Ltd., Maidstone, UK) to remove debris, concentrated with a rotary evaporator (EYELA, Bohemia, NY, USA), freeze-dried, and stored at $-80^{\circ} \mathrm{C}$ until use in experiments. 


\section{Cell culture and treatment}

Immortalized mouse skeletal C2C12 myoblasts were obtained from the American Type Culture Collection (CRL-1772 ${ }^{\mathrm{TM}}$, Manassas, VA, USA) and maintained in DMEM, which containing $10 \%$ FBS and $1 \%$ antibiotics, at $37^{\circ} \mathrm{C}$ in a humidified atmosphere containing $5 \% \mathrm{CO}_{2}$. $\mathrm{CFE}$ and $\mathrm{H}_{2} \mathrm{O}_{2}$ were dissolved in an appropriate amount of Milli-Q Water and diluted in the medium to the desired concentrations before treatment.

\section{Cell viability}

The MTT assay was performed for analysis of cell viability, as previously described [20]. Briefly, cells were treated with the indicated concentrations of CFE or $\mathrm{H}_{2} \mathrm{O}_{2}$ alone for $24 \mathrm{~h}$ or pretreated with CFE for $1 \mathrm{~h}$ and then treated with $\mathrm{H}_{2} \mathrm{O}_{2}$ for $24 \mathrm{~h}$. After treatment, MTT solution $(0.5 \mathrm{mg} / \mathrm{ml})$ was added to each well followed by incubation at $37^{\circ} \mathrm{C}$ for $3 \mathrm{~h}$. Subsequently, the supernatant was removed, and the formed formazan was dissolved with DMSO. The absorbance at $540 \mathrm{~nm}$ was then evaluated using a microplate reader (Beckman Coulter, Brea, CA, USA) at Core-Facility Center for Tissue Regeneration, Dong-eui University (Busan, Republic of Korea). Cell viability of each treatment group was expressed as a percentage of the absorbance of the control group.

\section{Measurement of ROS content}

DCF-DA staining was applied to measure the level of ROS produced in the cells. In brief, cells were pretreated with the indicated concentrations of CFE for $1 \mathrm{~h}$ prior to expose to $1 \mathrm{mM} \mathrm{H}_{2} \mathrm{O}_{2}$ for another $1 \mathrm{~h}$. The cells were stained with $10 \mu \mathrm{M} \mathrm{DCF}-\mathrm{DA}$ at $37^{\circ} \mathrm{C}$ for $20 \mathrm{~min}$ in the dark, then the levels of ROS production were assessed using a flow cytometer (Becton Dickinson) or observed under a fluorescence microscope (Carl Zeiss, Oberkochens, Germany), according to the method described previously [21].

\section{Comet assay}

The comet assay kit was used to evaluate the protective effect of CFE against $\mathrm{H}_{2} \mathrm{O}_{2}$-induced DNA damage, as previously described [22]. Briefly, cells were treated with $\mathrm{H}_{2} \mathrm{O}_{2}$ for $24 \mathrm{~h}$ or pretreated with CFE for $1 \mathrm{~h}$ followed by treatment with $\mathrm{H}_{2} \mathrm{O}_{2}$ for an additional $24 \mathrm{~h}$. Thereafter, cells were spread onto slide glasses pretreated with agarose, according to the manufacturer's instructions. After agarose was solidified, slides were submerged with a lysis solution supplied in the kit. Electrophoresis was then performed at $25^{\circ} \mathrm{C}$ for $20 \mathrm{~min}$ at $300 \mathrm{~mA}$ and $25 \mathrm{~V}$. After electrophoresis, cells were stained with $\mathrm{EtBr}$. The degree of comet formation was observed under a fluorescence microscope.

\section{Western blot analysis}


To analyze the expression of the target proteins by immunoblotting, cells cultured in the absence or presence of CFE for $1 \mathrm{~h}$ were treated with $\mathrm{H}_{2} \mathrm{O}_{2}$ for $24 \mathrm{~h}$. Total protein was extracted, as previously mentioned [23] or cytosolic and mitochondrial proteins were isolated for cytochrome $c$ expression analysis using a mitochondrial fraction kit, according to the manufacturer's instructions. After quantification of the isolated proteins, samples containing the equal amount of protein were separated on sodium dodecyl sulfate (SDS)-polyacrylamide gels and transferred to PVDF membranes for $1 \mathrm{~h}$ at room temperature (RT). The membranes were then probed with primary antibodies overnight at $4^{\circ} \mathrm{C}$. After washing the membranes with PBS-T (phosphate-buffered saline with Tween 20), membranes were immediately blotted with HRP-conjugated secondary antibodies for $1 \mathrm{~h}$ at RT. ECL was used to visualize the proteins of interest in accordance with the manufacturer's instructions.

\section{Annexin V-FITC/PI staining}

To quantitatively evaluate the degree of apoptosis, annexin V-FITC and PI double staining was performed. To this end, the cells treated as mentioned above were washed with PBS and stained using annexin V/PI solution for 20 min at RT, according to the manufacturer's protocol. Cells were then subjected to flow cytometry to quantify annexin V-positive cells as apoptosis-induced cells followed published procedures [24].

\section{DNA fragmentation assay}

To confirm the induction of DNA fragmentation, DNA gel electrophoresis was performed after cells were treated with $\mathrm{H}_{2} \mathrm{O}_{2}$ in the absence or presence of CFE as described above. Briefly, the collected cells were washed with PBS and resuspended in lysis buffer, as previously described [25]. The cells were incubated with $1 \mu \mathrm{g} / \mathrm{ml}$ RNase $A$ for $2 \mathrm{~h}$ at $37^{\circ} \mathrm{C}$, and then genomic DNA was extracted from the supernatant with phenol/chloroform/isoamyl alcohol. After precipitation with ethanol, the DNA was resolved by electrophoresis on $1.5 \%$ agarose gel at $70 \mathrm{~V}$. The gel was stained with $0.1 \mu \mathrm{g} / \mathrm{ml} \mathrm{EtBr}$ and then the DNA ladders were visualized with a UV transilluminator (Vilber, Collégien, France).

\section{DAPI staining}

To evaluate whether apoptosis was induced by observing morphological changes in the nucleus, DAPI staining was performed. In brief, cells were treated as described above, washed with PBS, and then fixed with $4 \%$ paraformaldehyde solution for $10 \mathrm{~min}$ at RT, according to a published method [20]. The cells were stained with $1 \mu \mathrm{g} / \mathrm{mL}$ DAPI solution for 10 min in the dark and washed again with PBS. Morphological changes of the nucleus were then observed under a fluorescence microscope.

\section{Analysis of MMP}


Flow cytometric analysis by $\mathrm{JC}-1$ staining was applied to monitor mitochondrial integrity. as previously described [26]. In brief, the collected cells were washed with PBS and stained with $10 \mu \mathrm{M} \mathrm{JC}-1$ solution in the dark for 20 min at RT, according to the manufacturer's procedure. After removing the supernatant, cells were washed again with PBS and analyzed using a flow cytometer to measure MMP. The loss of MMP was expressed as a ratio of $\mathrm{JC}-1$ aggregates, indicating the extent of mitochondrial depolarization to form JC-1 monomers.

\section{Caspase activity assay}

The activity of caspase- 9 and caspase- 3 was determined using the caspase activity assay kits according to the manufacturer's instructions. Briefly, after lysing cells to be measured, the supernatant was reacted with a reaction buffer per the recommendation of the manufacturer. The optical density of the reaction mixture of each sample after the reaction was measured at $405 \mathrm{~nm}$ using a microplate reader and expressed as a relative value [26].

\section{Statistical analysis}

Data are presented as mean \pm standard deviation (SD). All experiments were repeated three times. Statistical analysis was performed using Student's t-test, with GraphPad Prism 5 (GraphPad Software, Inc., La Jolla, CA, USA). Differences with $p<0.05$ were considered statistically significant.

\section{Results}

\section{CFE inhibits $\mathrm{H}_{2} \mathrm{O}_{2}$-induced cytotoxicity in $\mathrm{C} 2 \mathrm{C} 12$ cells}

To determine whether the decrease in the viability of $\mathrm{C} 2 \mathrm{C} 12$ cells by $\mathrm{H}_{2} \mathrm{O}_{2}$ was alleviated by $\mathrm{CFE}$, the cell viability was measured by MTT assay. No decrease in cell viability was observed for cells treated with CFE up to $0.4 \mathrm{mg} / \mathrm{ml}$ compared to untreated control cells (Supplementary File 2). In the cells treated with $\mathrm{H}_{2} \mathrm{O}_{2}$, the cell viability decreased significantly as the treatment concentration increased, and the cells treated with $1 \mathrm{mM} \mathrm{H}_{2} \mathrm{O}_{2}$ showed a viability of about $60 \%$ cells (Supplementary File 2). Based on these results, the treatment concentration of $\mathrm{H}_{2} \mathrm{O}_{2}$ to induce oxidative cytotoxicity was selected to be $1 \mathrm{mM}$, and the highest concentration for evaluating the protective effect of CFE was set to $0.4 \mathrm{mg} / \mathrm{ml}$. The results showed that pretreatment with CFE significantly attenuated $\mathrm{H}_{2} \mathrm{O}_{2}$-induced cell viability loss in a concentration-dependent manner (Supplementary File 2). At the same time, cell shrinkage and floatation due to $\mathrm{H}_{2} \mathrm{O}_{2}$ treatment were clearly protected by CFE pretreatment cells (Supplementary File 2).

\section{CFE blocks $\mathrm{H}_{2} \mathrm{O}_{2}$-induced elevation of ROS level in $\mathrm{C} 2 \mathrm{C} 12$ cells}


Since excessive ROS generation is considered to be a major cause of $\mathrm{H}_{2} \mathrm{O}_{2}$-mediated cell damage [3,27], we next investigated whether CFE could block it. The results of flow cytometry through DCF-DA staining showed that $\mathrm{H}_{2} \mathrm{O}_{2}$ significantly increased the level of ROS production (Figs. 1a and b). Consistent with this result, the DCF-fluorescence intensity increased dramatically in $\mathrm{H}_{2} \mathrm{O}_{2}$-treated cells than in the control (Fig. 1c). However, the increase in ROS content was significantly reduced by CFE pretreatment.

\section{CFE suppresses $\mathrm{H}_{2} \mathrm{O}_{2}$-induced DNA damage in $\mathrm{C} 2 \mathrm{C} 12$ cells}

Because continuous oxidative stress induces oxidative damage to intracellular macromolecules, including nucleic acids $[8,28]$, we further investigated whether CFE could counteract $\mathrm{H}_{2} \mathrm{O}_{2}$-induced DNA damage. As shown in Fig. 2a, the migration of damaged DNA fragments in $\mathrm{H}_{2} \mathrm{O}_{2}$-treated cells compared to control cells was clearly observed by comet assay, a single-cell DNA damage detection method [29]. In parallel, expression of phosphorylated nuclear histone H2A.X protein ( $\mathrm{p}-\mathrm{\gamma H} 2 \mathrm{~A} . \mathrm{X})$, an indicator of DNA double-strand breakage [30], was also strongly induced in cells treated with $\mathrm{H}_{2} \mathrm{O}_{2}$ alone (Fig. 2b). However, the formation of the DNA tail and the increased expression of p-yH2A.X by $\mathrm{H}_{2} \mathrm{O}_{2}$ was remarkably attenuated in the presence of $\mathrm{CFE}$, suggesting that the inhibitory effect of CFE against $\mathrm{H}_{2} \mathrm{O}_{2}$ induced DNA damage may be related to suppression of ROS generation.

\section{CFE protects $\mathrm{H}_{2} \mathrm{O}_{2}$-induced apoptosis in $\mathrm{C} 2 \mathrm{C} 12$ cells}

Excessive accumulation of ROS damages biomolecules within the cell and promotes activation of intracellular apoptotic pathways [31,32]. Therefore, we evaluated the protective efficacy of CFE against $\mathrm{H}_{2} \mathrm{O}_{2}$-induced apoptosis using the annexin V/PI double staining assay based on flow cytometry. As shown in Figs. $4 \mathrm{~A}$ and $\mathrm{B}$, although the frequency of annexin V-positive cells, an indicator of apoptosis, was very low in the control group, $\mathrm{H}_{2} \mathrm{O}_{2}$ treatment markedly increased their frequency, which was gradually decreased in a concentration-dependent manner in the presence of CFE. Consistent with these findings, the results of DAPI staining and agarose gel electrophoresis showed that chromatin condensation, formation of apoptotic bodies, and fragmentation of genomic DNA were increased in cells treated with $\mathrm{H}_{2} \mathrm{O}_{2}$ alone (Figs. $3 \mathrm{c}$ and d). However, these representative hallmarks of apoptosis were significantly reduced by CFE pretreatment, which indicated that CFE pretreatment significantly inhibited $\mathrm{H}_{2} \mathrm{O}_{2}$-induced apoptosis, thereby restoring cell viability.

\section{CFE alleviates $\mathrm{H}_{2} \mathrm{O}_{2}$-induced mitochondrial dysfunction in $\mathrm{C} 2 \mathrm{C} 12$ cells}


The accumulation of ROS serves as a signal for initiating of intrinsic apoptosis by impaired mitochondrial function, and loss of MMP is considered as an indicator of mitochondrial dysfunction [10, 28]. Therefore, flow cytometry analysis by JC-1 staining was performed to evaluate the change in MMP in the inhibition of $\mathrm{H}_{2} \mathrm{O}_{2}$-induced apoptosis by CFE. As shown in Figs. $4 a$ and $b$, the ratio of JC-1 aggregates to JC-1 monomers, which indicates the dissipation of mitochondrial MMP, was significantly reduced in the cells treated with $\mathrm{H}_{2} \mathrm{O}_{2}$ compared to the control group. However, this effect was obviously restored by pretreatment of CFE, indicating CFE mitigated mitochondrial depolarization by $\mathrm{H}_{2} \mathrm{O}_{2}$ in $\mathrm{C} 2 \mathrm{C} 12$ cells. It is well known that loss of MMP is accompanied by the release of apoptosis-inducing factors such as cytochrome $c$ from the mitochondria into the cytoplasm $[3,6]$. Our immunoblotting analysis revealed that the expression of cytochrome $c$ in the cytoplasm of $\mathrm{H}_{2} \mathrm{O}_{2}$-treated cells was increased, while its expression in the mitochondria was decreased (Fig. 4c). However, $\mathrm{CFE}$ pretreatment reduced $\mathrm{H}_{2} \mathrm{O}_{2}$-induced cytosolic release of cytochrome $c$ in a concentration-dependent manner, suggesting that CFE contributed to the protection of $\mathrm{C} 2 \mathrm{C} 12$ cells from $\mathrm{H}_{2} \mathrm{O}_{2}$-induced apoptosis by maintaining mitochondrial stability.

\section{CFE modulates the expression of Bcl-2 family proteins and the activation of caspases in $\mathrm{H}_{2} \mathrm{O}_{2}$-treated $\mathrm{C} 2 \mathrm{C} 12$ cells}

To further investigate the mechanisms involved in the anti-apoptotic action of CFE against $\mathrm{H}_{2} \mathrm{O}_{2}$, the effects of CFE on the expression of proteins belonging to the $\mathrm{Bcl}-2$ family and the activation of caspases in $\mathrm{H}_{2} \mathrm{O}_{2}$-treated cells were investigated. Our Western blot analysis showed that $\mathrm{H}_{2} \mathrm{O}_{2}$ downregulated the expression of anti-apoptotic Bcl-2 protein and upregulated the expression of pro-apoptotic Bax (Fig. 5a). Additionally, as the expression of inactive forms of caspase- 9 and caspase- 3 was decreased in $\mathrm{H}_{2} \mathrm{O}_{2}$ stimulated cells, their enzymatic activity was increased, which correlated with the degradation of poly (ADP-ribose) polymerase (PARP) (Figs. 5b-d). However, these changes were gradually alleviated with increasing CFE pretreatment concentration.

\section{Discussion}

In the present study, we investigated the effect of CFE on oxidative stress-induced cytotoxicity using $\mathrm{H}_{2} \mathrm{O}_{2}$, a freely diffusible ROS, to mimic oxidative damage in $\mathrm{C} 2 \mathrm{C} 12$ myoblasts. The results of the current study showed that CFE significantly inhibited $\mathrm{H}_{2} \mathrm{O}_{2}$-induced oxidative damage, which was correlated with its ability to block ROS generation.

As is well known, oxidative stress induced by ROS results in cellular injury through DNA damage and apoptosis in most cells, including muscle cells $[10,33]$. In this study, the results of comet assay showed that CFE effectively inhibited $\mathrm{H}_{2} \mathrm{O}_{2}$-induced comet tail formation. In addition, the expression of p-yH2A.X induced by $\mathrm{H}_{2} \mathrm{O}_{2}$ was largely reversed in the presence of CFE. Although further studies are needed to understand the exact mechanism of DNA damage inhibition related to antioxidant efficacy by CFE, these data demonstrate that CFE has a significant ameliorating ability for $\mathrm{H}_{2} \mathrm{O}_{2}$-induced DNA damage in C2C12 
myoblasts. This result is in good agreement with the previous results that DNA damage caused by oxidative stimulation was blocked by Corni Fructus extract or its bioactive substances [18, 34]. The present study also showed that pretreatment with CFE blocked $\mathrm{H}_{2} \mathrm{O}_{2}$-induced apoptosis in the results of various indices evaluating apoptosis.

Previous studies have shown that excessive accumulation of ROS disrupts the equilibrium of the intracellular redox system and activates the mitochondrial permeability transition by targeting mitochondrial membrane proteins $[10,26]$. As a result, MMP is lost and the mitochondrial apoptogenic proteins such as cytochrome $c$ released into the cytoplasm binds to apoptotic protease activating factor 1 to form apoptosome, thereby initiating the activation of the caspase cascade. This is a typical process that activates the caspase-dependent intrinsic apoptosis pathway, and caspase- 9 activated by the formation of apoptosome enhances the activation of effector caspases, including caspase-3 [28, 31]. Activated effector caspases complete apoptosis through the breakdown of proteins necessary for cell survival $[28,31]$. Indeed, we observed the release of cytochrome $c$ from mitochondria to the cytoplasm due to disruption of mitochondrial membrane stability in $\mathrm{H}_{2} \mathrm{O}_{2}$-treated $\mathrm{C} 2 \mathrm{C} 12$ cells, consistent with previous studies $[35,36]$. In addition, caspase- 9 and caspase-3 were activated, which correlated with the degradation of PARP, a representative substrate protein cleaved by activated effector caspases $[31,36]$. However, these effects were reversed in the presence of CFE. These results suggest that mitochondrial integrity in $\mathrm{H}_{2} \mathrm{O}_{2}$-treated $\mathrm{C} 2 \mathrm{C} 12$ myoblasts was maintained by pretreatment with $\mathrm{CFE}$, thereby blocking the mitochondria-mediated intrinsic apoptosis pathway.

The intrinsic apoptosis pathway is tightly regulated by the Bcl-2 family members consisting of antiapoptotic and pro-apoptotic proteins, and the interaction between them acts as a determinant of apoptosis $[8,31]$. Consistent with the results of this study, $\mathrm{H}_{2} \mathrm{O}_{2}$ has been reported to regulate the expression level of $\mathrm{Bcl}-2$ family proteins involved in the intrinsic apoptosis pathway by stimulating Bax and inhibiting $\mathrm{Bcl}-2$ expression in various cell types including $\mathrm{C} 2 \mathrm{C} 12$ cells $[28,31]$. In this study, the increased ratio of $\mathrm{Bax} / \mathrm{Bcl}-2$ expression by $\mathrm{H}_{2} \mathrm{O}_{2}$ was also greatly counteracted by CFE pretreatment. Proapoptotic proteins such as Bax activated by apoptosis-inducing stimuli relocate from the cytoplasm to the mitochondrial outer membrane to form a mitochondrial permeable transition pore. However, antiapoptotic proteins, including Bcl-2, have the opposite effect, thereby inhibiting the release of cytochrome $c$ from the mitochondria to the cytoplasm [28,32]. Therefore, our findings suggest that the increase in the relative expression of $\mathrm{Bcl}-2$ to $\mathrm{Bax}$ by $\mathrm{CFE}$ in $\mathrm{C} 2 \mathrm{C} 12$ cells plays a decisive role in blocking the induction of apoptosis by $\mathrm{H}_{2} \mathrm{O}_{2}$. Taken together, it is presumed that CFE might be an effective therapeutic antioxidant to prevent oxidative damage by scavenging ROS generation, which is the cause of mitochondrial apoptosis pathway. However, further studies are needed on the role of CFE in intracellular signaling pathways involved in antioxidant mechanisms. In addition, the identification of the physiologically active ingredients contained in CFE, verification of their effectiveness, and follow-up studies through in vivo animal experiments should be performed.

\section{Conclusion}


In the present study, we evaluated the effect of CFE on oxidative stress-mediated cytotoxicity using $\mathrm{H}_{2} \mathrm{O}_{2}$ to mimic oxidative stress in $\mathrm{C} 2 \mathrm{C} 12$ myoblasts. Our results showed that CFE significantly blocked $\mathrm{H}_{2} \mathrm{O}_{2}$-induced DNA damage and apoptotic cell death, which was associated with blocking ROS generation. We also found that the apoptosis-blocking effect of CFE was mediated by inhibition of activation of the caspase cascade through regulation of Bcl-2 family proteins and inhibition of cytosolic release of cytochrome $c$, leading to inhibition of the mitochondria-mediated apoptosis pathway.

\section{Declarations}

\section{Acknowledgments}

This work was supported by the Ministry of Science and ICT and the National Research Foundation of Korea (NRF-2021R1A2C1008515).

\section{Author contributions}

SOK, performed project administration, methodology, validation, data curation, experiment, visualization, and writing of original draft. YHC \& EHL, preformed supervision, conceptualization, data curation, writing review and editing. All authors have read and agreed to the published this manuscript.

\section{Conflict of interest}

All authors declare no conflicts of interest.

\section{Ethical approval}

None.

\section{References}

1. Mukund K, Subramaniam S (2020) Skeletal muscle: A review of molecular structure and function, in health and disease. Wiley Interdiscip Rev Syst Biol Med 12:e1462. https://doi.org/10.1002/wsbm.1462

2. Bell RA, Al-Khalaf M, Megeney LA (2016) The beneficial role of proteolysis in skeletal muscle growth and stress adaptation. Skelet Muscle 6:16. https://doi.org/10.1186/s13395-016-0086-6

3. Benhar M (2020) Oxidants, Antioxidants and thiol redox switches in the control of regulated cell death pathways. Antioxidants (Basel) 9:309. https://doi.org/10.3390/antiox9040309

4. He L, He T, Farrar S, Ji L, Liu T, Ma X (2017) Antioxidants maintain cellular redox homeostasis by elimination of reactive oxygen species. Cell Physiol Biochem 44:532-553. 
https://doi.org/10.1159/000485089

5. Mosca N, Petrillo S, Bortolani S, Monforte M, Ricci E, Piemonte F, Tasca G (2021) Redox homeostasis in muscular dystrophies. Cells 10:1364. https://doi.org/10.3390/cells10061364

6. Bouviere J, Fortunato RS, Dupuy C, Werneck-de-Castro JP, Carvalho DP, Louzada RA (2021) Exercisestimulated ROS sensitive signaling pathways in skeletal muscle. Antioxidants (Basel) 10:537. https://doi.org/10.3390/antiox10040537

7. Qaisar R, Bhaskaran S, Premkumar P, Ranjit R, Natarajan KS, Ahn B, Riddle K, Claflin DR, Richardson A, Brooks SV, Van Remmen H (2018) Oxidative stress-induced dysregulation of excitation-contraction coupling contributes to muscle weakness. J Cachexia Sarcopenia Muscle 9:1003-1017. https://doi.org/10.1002/jcsm.12339

8. Jakubczyk K, Dec K, Kałduńska J, Kawczuga D, Kochman J, Janda K (2020) Reactive oxygen species - sources, functions, oxidative damage. Pol Merkur Lekarski 48:124-127. https://pubmed.ncbi.nlm.nih.gov/32352946/

9. Majumder A, Singh M, George AK, Tyagi SC (2019) Restoration of skeletal muscle homeostasis by hydrogen sulfide during hyperhomocysteinemia-mediated oxidative/ER stress condition (1). Can J Physiol Pharmacol 97:441-456. https://doi.org/10.1139/cjpp-2018-0501

10. Brillo V, Chieregato L, Leanza L, Muccioli S, Costa R (2021) Mitochondrial dynamics, ROS, and cell signaling: A blended overview. Life (Basel) 11:332. https://doi.org/10.3390/life11040332

11. Gao X, Liu Y, An Z, Ni J (2021) Active components and pharmacological effects of Cornus officinalis: Literature review. Front Pharmacol 12:63344. https://doi.org/10.3389/fphar.2021.633447

12. Huang J, Zhang Y, Dong L, Gao Q, Yin L, Quan H, Chen R, Fu X, Lin D (2018) Ethnopharmacology, phytochemistry, and pharmacology of Cornus officinalis Sieb. et Zucc. J Ethnopharmacol 213:280301. https://doi.org/10.1016/j.jep.2017.11.010

13. Wu Y, Wang X, Shen B, Kang L, Fan E (2013) Extraction, structure and bioactivities of the polysaccharides from Fructus corni. Recent Pat Food Nutr Agric 5:57-61. https://doi.org/10.2174/2212798411305010009

14. Xu R, Zeng M, Wu Y, Wang S, Zhang B, Zhang J, Kan Y, Li B, Cao B, Zheng X, Feng W (2021) Acetone extract of Cornus officinalis leaves exerts anti-melanoma effects via inhibiting STAT3 signaling. Targets Ther 14:3487-3501. https://doi.org/10.2147/0TT.S308371

15. Park C, Cha HJ, Lee H, Kim GY, Choi YH (2021) The regulation of the TLR4/NF-KB and Nrf2/HO-1 signaling pathways is involved in the inhibition of lipopolysaccharide-induced inflammation and oxidative reactions by morroniside in RAW 264.7 macrophages. Arch Biochem Biophys 30:706:108926. https://doi.org/10.1016/j.abb.2021.108926

16. Tian W, Zhao J, Lee JH, Akanda MR, Cho JH, Kim SK, Choi YJ, Park BY (2019) Neuroprotective effects of Cornus officinalis on stress-induced hippocampal deficits in rats and $\mathrm{H}_{2} \mathrm{O}_{2}$-induced neurotoxicity in SH-SY5Y neuroblastoma cells. Antioxidants (Basel) 9:27. https://doi.org/10.3390/antiox9010027 
17. Hwang KA, Hwang YJ, Song J (2016) Antioxidant activities and oxidative stress inhibitory effects of ethanol extracts from Cornus officinalis on raw 264.7 cells. BMC Complement Altern Med 16:196. https://doi.org/10.1186/s12906-016-1172-3

18. Hong SY, Jeong WS, Jun M (2012) Protective effects of the key compounds isolated from Corni fructus against beta-amyloid-induced neurotoxicity in PC12 cells. Molecules 17:10831-10845. https://doi.org/10.3390/molecules170910831

19. Hwangbo H, Kwon DH, Choi EO, Kim MY, Ahn KI, Ji SY, Kim JS, Kim KI, Park NJ, Kim BH, Kim GY, Hong SH, Park C, Jeong JS, Choi YH (2014) Corni Fructus attenuates testosterone-induced benign prostatic hyperplasia by suppressing 5alpha-reductase and androgen receptor expression in rats. Nutr Res Pract 12:378-386. https://doi.org/10.4162/nrp.2018.12.5.378

20. Choi YH (2021) Trans-cinnamaldehyde protects C2C12 myoblasts from DNA damage, mitochondrial dysfunction and apoptosis caused by oxidative stress through inhibiting ROS production. Genes Genomics 43:303-312. https://doi.org/10.1007/s13258-020-00987-9

21. Bae CS, Lee CM, Ahn T (2020) Encapsulation of apoptotic proteins in lipid nanoparticles to induce death of cancer cells. Biotechnol Bioprocess Eng 5:264-271. https://doi.org/10.1007/s12257-0190409-7

22. Volobaev VP, Serdyukova ES, Kalyuzhnaya EE, Schetnikova EA, Korotkova AD, Naik AA, Bach SN, Prosekov AY, Larionov AV (2020) Investigation of the genotoxic effects of fluoride on a bone tissue model. Toxicol Res 36:337-342. https://doi.org/10.1007/s43188-020-00039-0

23. Choi MJ, Mukherjee S, Yun JW (2021) Loss of ADAMTS15 promotes browning in 3T3-L1 white adipocytes via activation of $\beta 3$-adrenergic receptor. Biotechnol Bioprocess Eng 26:188-200. https://doi.org/10.1007/s12257-021-0036-y

24. Ojima T, Kawami M, Yumoto R, Takano M (2021) Differential mechanisms underlying methotrexateinduced cell death and epithelial-mesenchymal transition in A549 cells. Toxicol Res 37:293-300. https://doi.org/10.1007/s43188-020-00067-w

25. Park C, Lee H, Hong SH, Kim JH, Park SK, Jeong JW, Kim GY, Hyun JW, Yun SJ, Kim BW, Kim WJ, Choi YH (2019) Protective effect of diphlorethohydroxycarmalol against oxidative stress-induced DNA damage and apoptosis in retinal pigment epithelial cells. Cutan Ocul Toxicol 38:98-308. https://doi.org/10.1080/15569527.2019.1613425

26. Liang Y, Kong D, Zhang Y, Li S, Li Y, Ramamoorthy S, Ma J (2020) Fisetin inhibits cell proliferation and induces apoptosis via JAK/STAT3 signaling pathways in human thyroid TPC 1 cancer cells. Biotechnol Bioprocess Eng 25:197-205. https://doi.org/10.1007/s12257-019-0326-9

27. Panieri E, Gogvadze V, Norberg E, Venkatesh R, Orrenius S, Zhivotovsky B (2013) Reactive oxygen species generated in different compartments induce cell death, survival, or senescence. Free Radic Biol Med 57:176-187. https://doi.org/10.1016/j.freeradbiomed.2012.12.024

28. Xiong S, Mu T, Wang G, Jiang X (2014) Mitochondria-mediated apoptosis in mammals. Protein Cell 5:737-749. https://doi.org/10.1007/s13238-014-0089-1 
29. Cordelli E, Bignami M, Pacchierotti F (2021) Comet assay: a versatile but complex tool in genotoxicity testing. Toxicol Research 10:68-78. https://doi.org/10.1093/toxres/tfaa093

30. Raavi V, Perumal V, Paul FD S (2019) Potential application of gamma-H2AX as a biodosimetry tool for radiation triage. Mutat Res Rev Mutat Res 787:108350.

https://doi.org/10.1016/j.mrrev.2020.108350

31. Dadsena S, King LE, García-Sáez AJ (2021) Apoptosis regulation at the mitochondria membrane level. Biochim Biophys Acta Biomembr 31:183716. https://doi.org/10.1016/j.bbamem.2021.183716

32. Suhaili SH, Karimian H, Stellato M, Aguilar MI, Lee TH (2017) Mitochondrial outer membrane permeabilization: a focus on the role of mitochondrial membrane structural organization. Biophys Rev 9:443-457. https://doi.org/10.1007/s12551-017-0308-0

33. Jiang Q, Yin J, Chen J, Ma X, Wu M, Liu G, Yao K, Tan B, Yin Y (2020) Mitochondria-targeted antioxidants: A step towards disease treatment. Oxid Med Cell Longev 2020:8837893. https://doi.org/10.1155/2020/8837893

34. Fernando PDSM, Piao MJ, Zhen AX, Ahn MJ, Yi JM, Choi YH, Hyun JW (2020) Extract of Cornus officinalis protects keratinocytes from particulate matter-induced oxidative stress. Int J Med Sci 17:63-70. https://doi.org/10.7150/ijms.36476

35. Chen W, Zhang YN, Jia QQ, Ji A, Shao SX, Zhang L, Gong M, Yin Q, Huang XL (2020) MicroRNA-214 protects $\mathrm{L} 6$ skeletal myoblasts against hydrogen peroxide-induced apoptosis. Free Radic Res 54:162-172. https://doi.org/10.1080/10715762.2020.1730828

36. Dam AD, Mitchell AS, Quadrilatero J (2013) Induction of mitochondrial biogenesis protects against caspase-dependent and caspase-independent apoptosis in L6 myoblasts. Biochim Biophys Acta 1833:3426-3435. https://doi.org/10.1016/j.bbamcr.2013.04.014

\section{Figures}




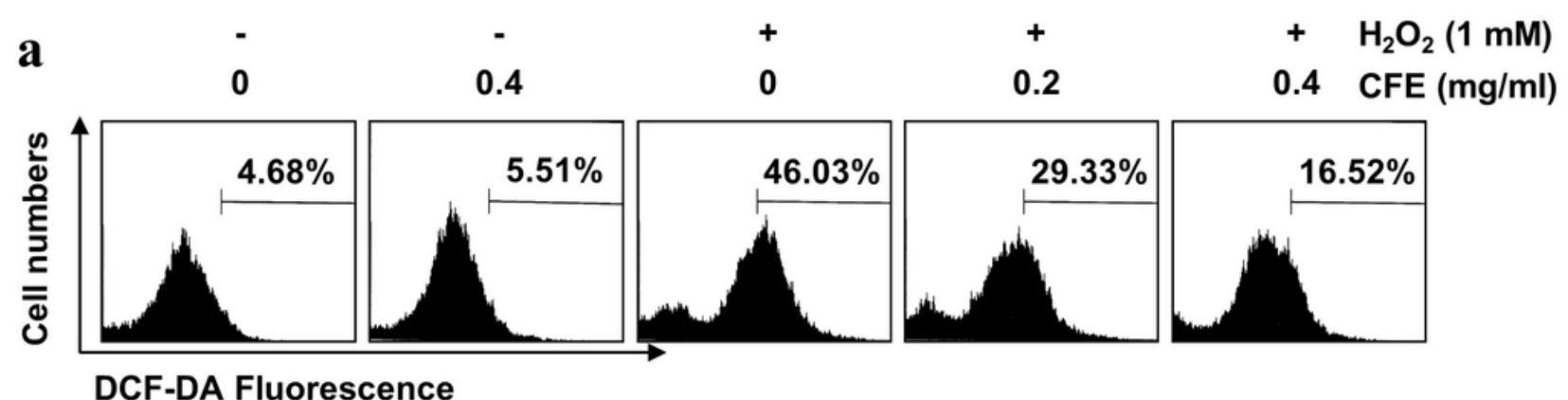

b

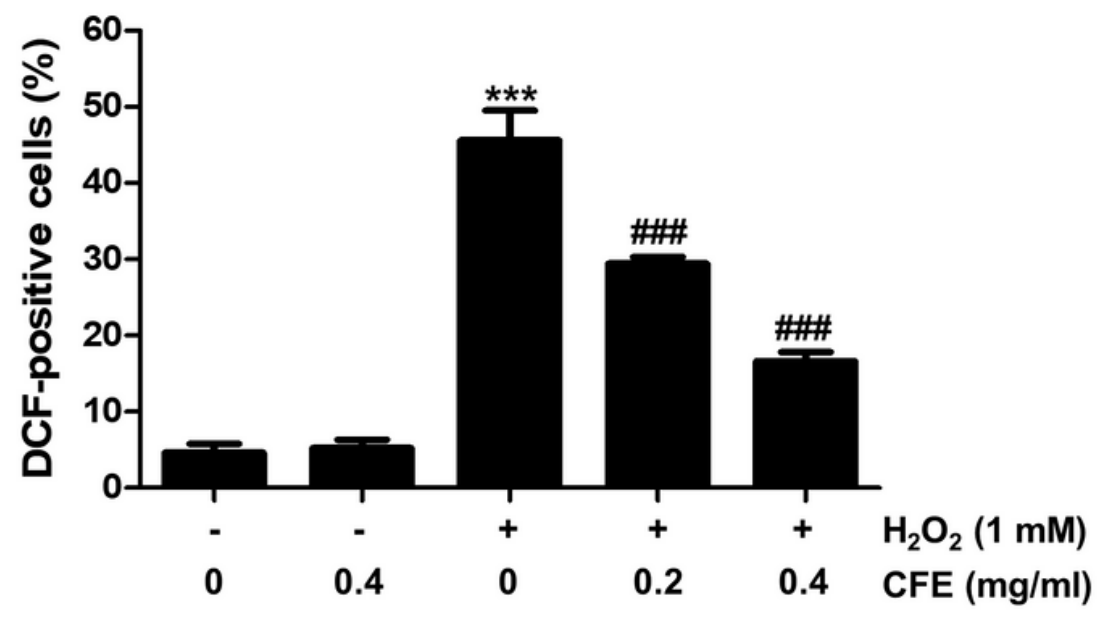

c

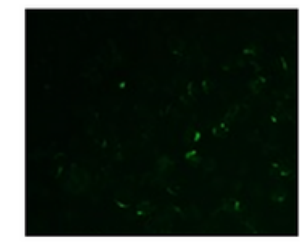

0.4

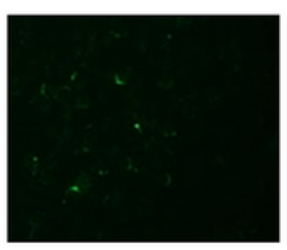

\begin{abstract}
$+$
\end{abstract}
0

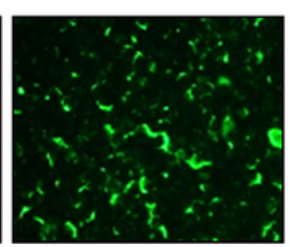

$+$

0.2

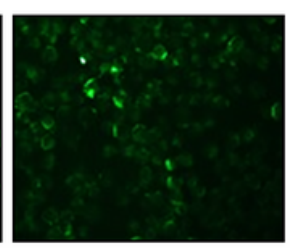

$+\mathrm{H}_{2} \mathrm{O}_{2}(1 \mathrm{mM})$

0.4 CFE $(\mathrm{mg} / \mathrm{ml})$

\section{Figure 1}

Inhibition of $\mathrm{H} 2 \mathrm{O} 2$-induced ROS generation by CFE in $\mathrm{C} 2 \mathrm{C} 12$ cells. Cells were treated with the indicated concentrations of CFE and $\mathrm{H} 2 \mathrm{O} 2$ for $1 \mathrm{~h}$ or pretreated with CFE for $1 \mathrm{~h}$ prior to exposure to $\mathrm{H} 2 \mathrm{O} 2 \mathrm{for} 1 \mathrm{~h}$. Intracellular ROS levels were determined by flow cytometry ( $a$ and b) or fluorescence microscopy (c) after staining with DCF-DA. (b) Ratios of DCF-positive cells were statistically quantified. Results were expressed as mean \pm SD of three independent experiments ( ${ }^{\star \star *} p<0.001$ vs. control cells; \#\#\# $p<0.001$ vs. $\mathrm{H} 2 \mathrm{O} 2$ treated cells). (c) Representative fluorescence microscopy images were presented. 
a

0

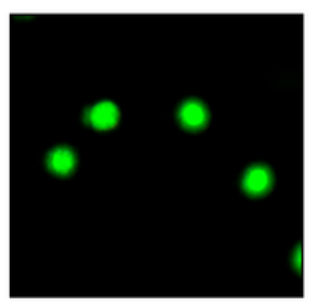

b
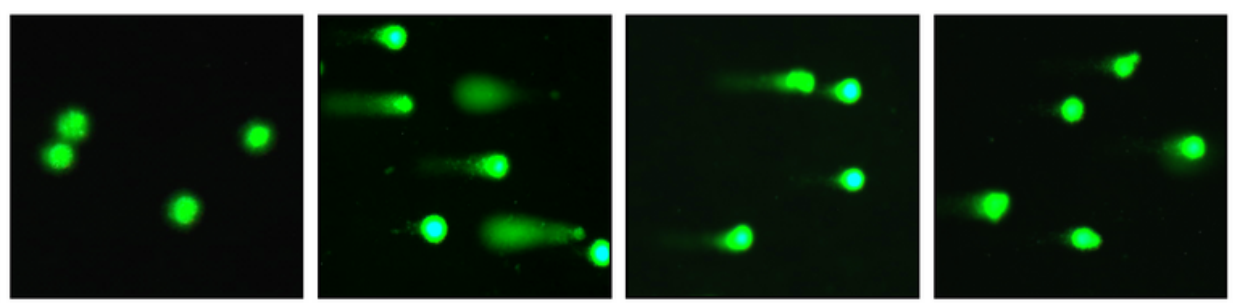

$\mathrm{H}_{2} \mathrm{O}_{2}(1 \mathrm{mM})$

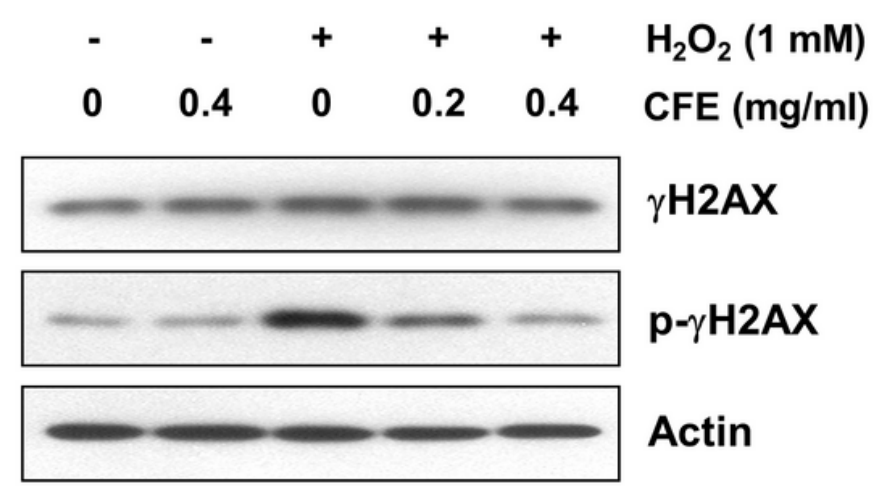

Figure 2

Protection H2O2-induced DNA damage by CFE in C2C12 cells. Cells were treated the indicated concentrations of CFE and $\mathrm{H} 2 \mathrm{O} 2$ for $1 \mathrm{~h}$ or pretreated with CFE for $1 \mathrm{~h}$ prior to exposure to $\mathrm{H} 2 \mathrm{O} 2$ for $24 \mathrm{~h}$. (a) DNA damage was detected by a comet assay. Representative images were shown. (b) For Western blot analysis, the extracted total proteins were subjected to SDS-polyacrylamide gel electrophoresis and then transferred to PVDF membranes. Membranes containing proteins were probed with the indicated antibodies. Anti-actin immunoblotting revealed relative amounts of protein in each lane. 
a

-
0.4

$+$

$+\mathrm{H}_{2} \mathrm{O}_{2}(1 \mathrm{mM})$

0

0.4

0

0.2

$0.4 \mathrm{CFE}(\mathrm{mg} / \mathrm{ml})$
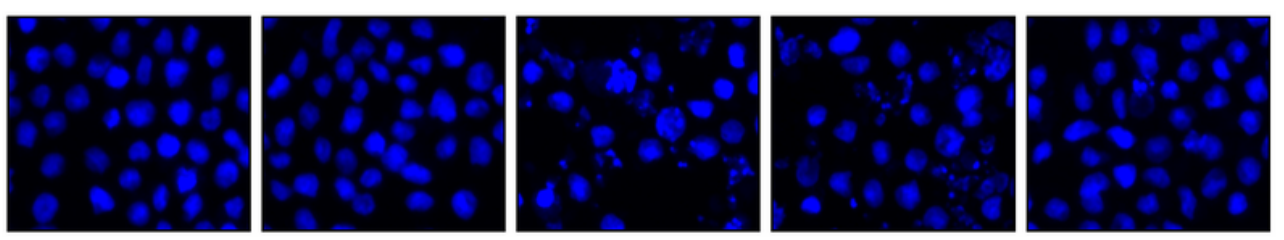

b

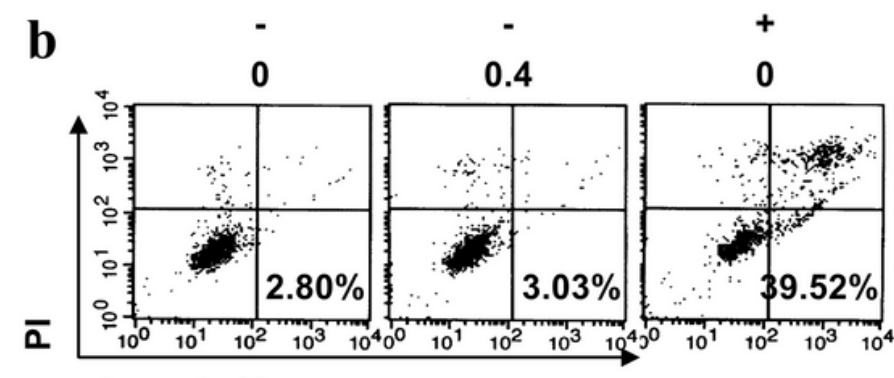

$+$

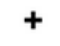

$+\mathrm{H}_{2} \mathrm{O}_{2}(1 \mathrm{mM})$

0.2

$0.4 \mathrm{CFE}(\mathrm{mg} / \mathrm{ml})$

Annexin V

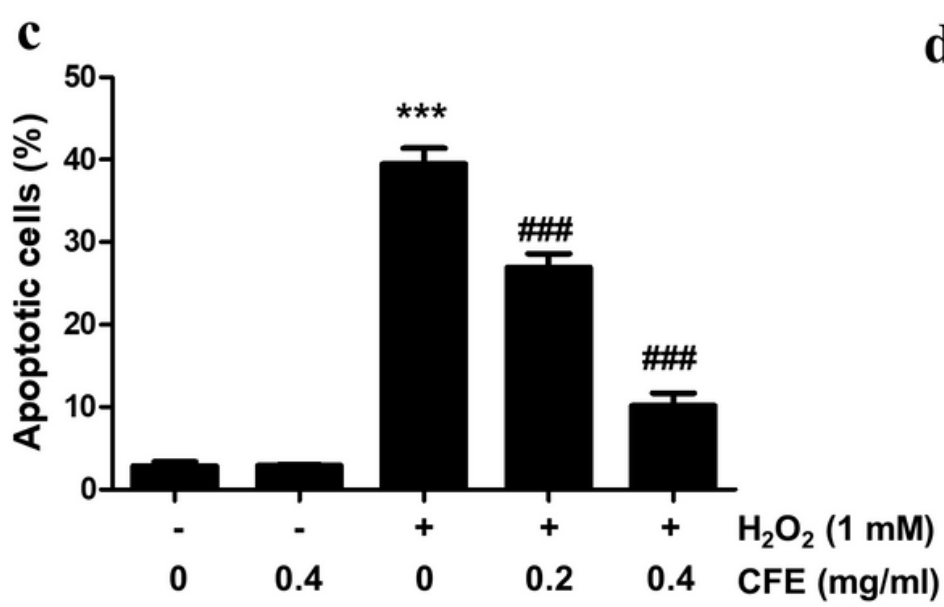

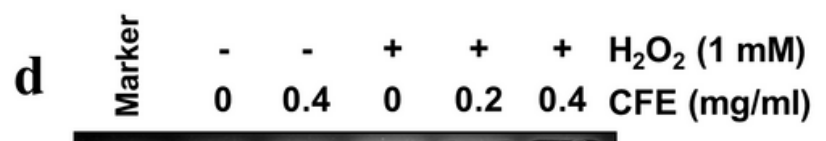

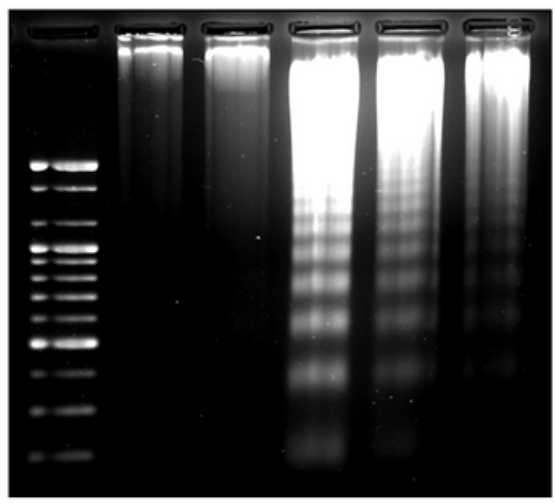

\section{Figure 3}

Suppression of $\mathrm{H} 2 \mathrm{O} 2$-induced apoptosis by CFE in $\mathrm{C} 2 \mathrm{C} 12$ cells ( $\mathrm{A}$ and $\mathrm{B}$ ) After treatment as above, the cells were stained with annexin V/PI and then analyzed by flow cytometry. (a) Representative flow histograms were presented, and the percentages of apoptotic cells were indicated in the lower right panel. (b) Quantitative analysis of apoptotic cells in percentage. Data points in the graph represent mean \pm SD from triplicate experiments ( ${ }^{\star \star *} p<0.001$ vs. control cells; \#\#\# $p<0.001$ vs. H2O2 treated cells). (c) Induction of apoptosis was also evaluated by measuring cells with condensed nuclei after DAPI staining. Representative photomicrographs were shown. (d) Fragmentation of genomic DNA isolated from cells was evaluated by $1.5 \%$ agarose gel electrophoresis and staining with $\mathrm{EtBr}$. 
$\mathbf{a}$

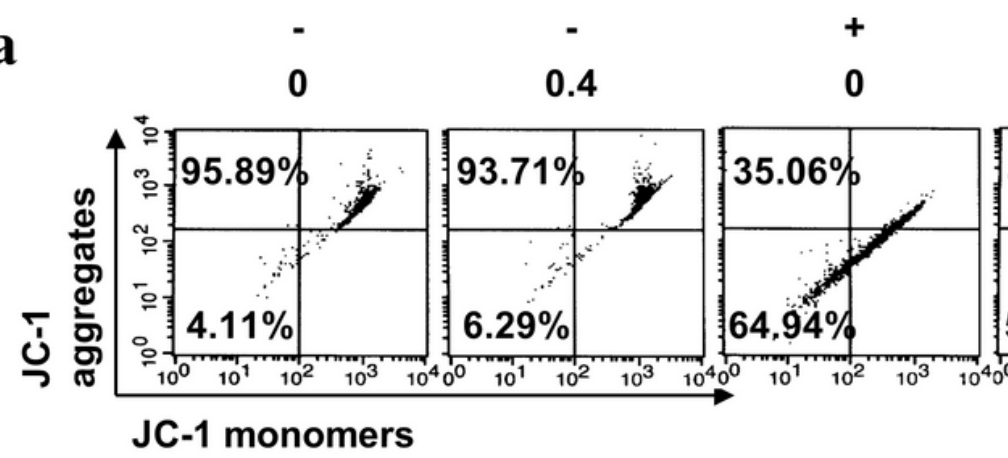

$+$

0.2

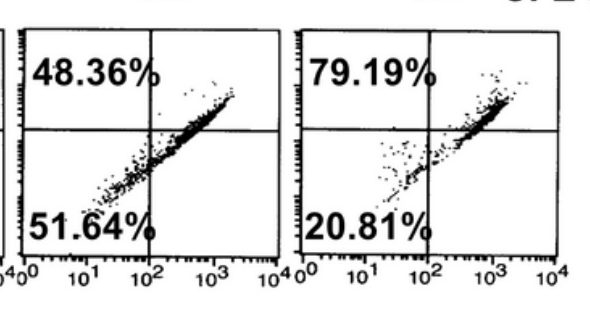

b

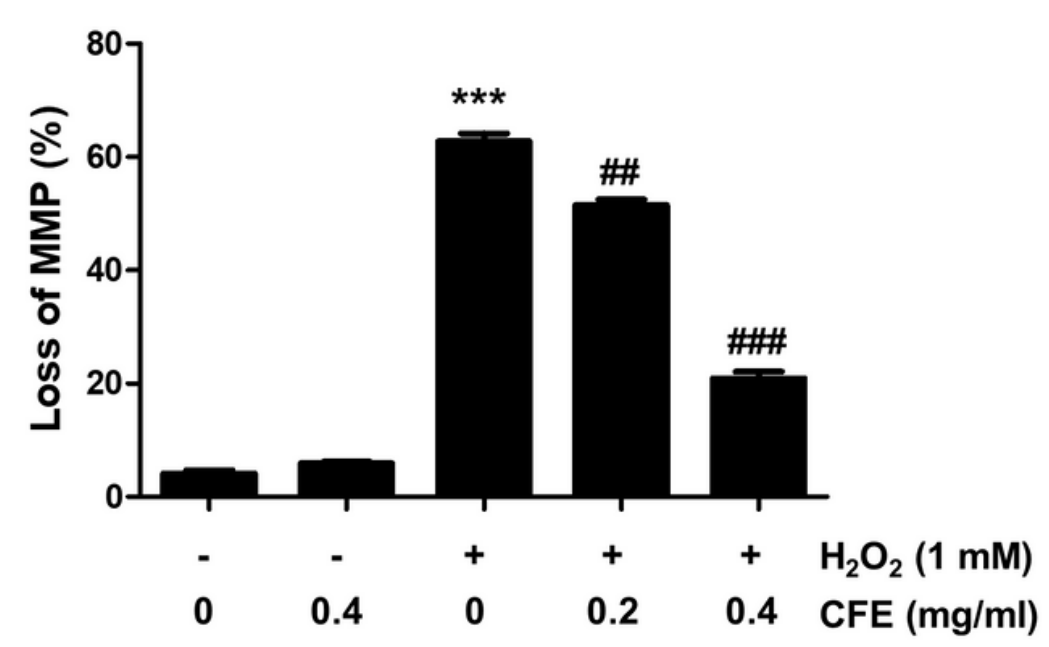

c

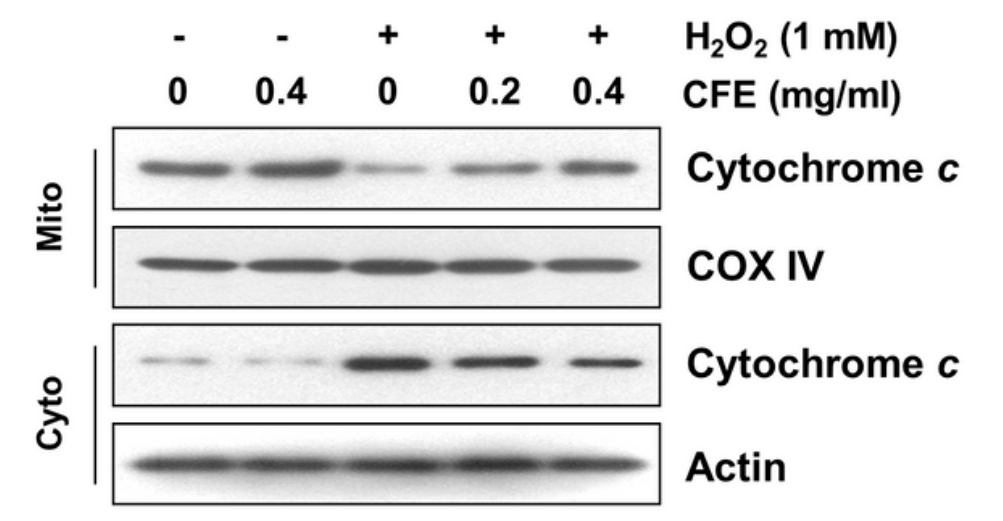

Figure 4

Attenuation of $\mathrm{H} 2 \mathrm{O} 2$-induced mitochondrial dysfunction, and cytosolic release of cytochrome c by CFE in C2C12 cells. ( $a$ and $b$ ) After treatment as above, MMP was assessed by flow cytometry after JC-1 staining. (a) Representative profiles of flow cytometry analysis were shown. (b) Ratios of JC-1 aggregates to monomers were presented as mean \pm SD of triplicate independent experiments ( $\star \star \star ~ p<0.001$ vs. control cells; \#\# $p<0.01$ and \#\#\# $p<0.001$ vs. H2O2 treated cells). (c) Expression of cytochrome $c$ using mitochondrial and cytoplasmic fractions was measured by Western blot analysis. Cytochrome c oxidase subunit IV (COX IV) and actin were analyzed as internal controls for mitochondrial and cytosolic fractions, respectively. Mito, mitochondrial fraction; Cyto, cytoplasmic fraction 
a
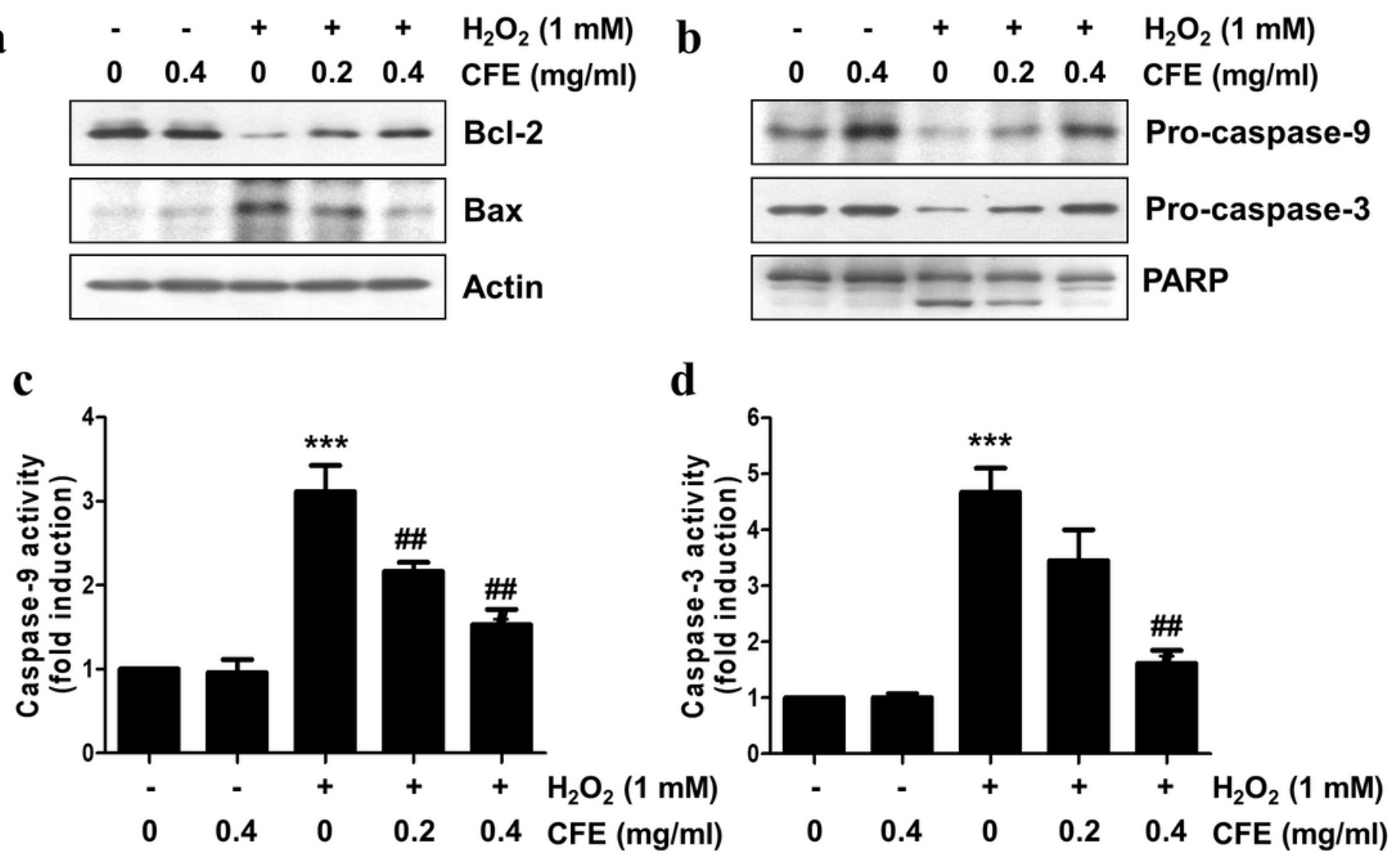

Figure 5

Effect of CFE on expression of Bcl-2, Bax, caspases and PARP, and activity of caspases in H2O2-treated C2C12 cells. (a) After treatment, expression of the indicated proteins was detected by Western blot analysis using total proteins isolated from cells. Actin was used to determine equal amount of protein loaded into each lane. (b) Activity of caspase-3 and caspase-9 was measured using colorimetric caspase

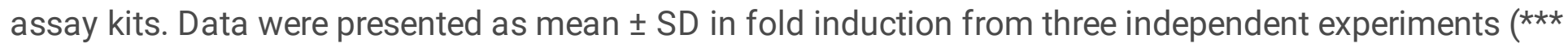
$p<0.001$ vs. control cells; \#* $p<0.01$ and \#\#\# $p<0.001$ vs. $\mathrm{H} 202$ treated cells).

\section{Supplementary Files}

This is a list of supplementary files associated with this preprint. Click to download.

- SupplementaryMaterial.pdf 